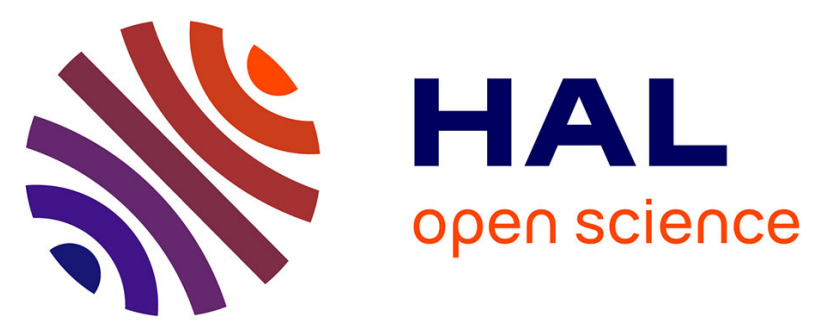

\title{
First record of shield-backed katydids in Madagascar with the description of a new genus and three new species (Orthoptera: Ensifera: Tettigoniidae: Tettigoniinae: Arytropteridini) \\ Sylvain Hugel
}

\section{To cite this version:}

Sylvain Hugel. First record of shield-backed katydids in Madagascar with the description of a new genus and three new species (Orthoptera: Ensifera: Tettigoniidae: Tettigoniinae: Arytropteridini). Zootaxa, 2019, 4706 (4), pp.546-560. 10.11646/zootaxa.4706.4.4 . hal-02881352

\section{HAL Id: hal-02881352 https://hal.science/hal-02881352}

Submitted on 24 Nov 2020

HAL is a multi-disciplinary open access archive for the deposit and dissemination of scientific research documents, whether they are published or not. The documents may come from teaching and research institutions in France or abroad, or from public or private research centers.
L'archive ouverte pluridisciplinaire HAL, est destinée au dépôt et à la diffusion de documents scientifiques de niveau recherche, publiés ou non, émanant des établissements d'enseignement et de recherche français ou étrangers, des laboratoires publics ou privés. 
First record of shield-backed katydids in Madagascar with the description of a new genus and three new species (Orthoptera: Ensifera: Tettigoniidae: Tettigoniinae: Arytropteridini).

by Sylvain Hugel

INCI, UPR 3212 CNRS, Université de Strasbourg, 8, allée du Général Rouvillois, F-67000 Strasbourg Cedex.E-mail: hugels@inci-cnrs.unistra.fr

\begin{abstract}
Shield-backed katydids of tribe Arytropteridini Caudell, 1908 are recorded for the first time in Madagascar. The new genus Toliaridectes $n$. gen. is proposed to include three new species from the south west of the island: Toliaridectes meridionalis n. gen. n. sp., Toliaridectes wendenbaumi n. gen. n. sp. and Toliaridectes antsycurvis n. gen. n. sp.. Elements of biology of Toliaridectes $\mathrm{n}$. gen. are given and the call of Toliaridectes antsycurvis n. gen. $\mathrm{n}$. sp. is described. The taxonomic position of Arytropteridini is discussed.
\end{abstract}

Key words: Orthoptera, endemism, South Western Indian Ocean islands, Madagascar, bush cricket.

\title{
Introduction
}

Whereas Malagasy grasshoppers are quite well known, particularly the day-active acridoids, Malagasy crickets and bush crickets have been relatively neglected until recently. Indeed, over the last decade, several groups have reviewed and/or described new bush cricket species from Madagascar (e.g. Heller et al 2018, 2019, Gorochov 2017, Hugel 2012, Ünal \& Beccaloni 2017). Interestingly, as for many other groups in Madagascar, Orthoptera display a relatively low overlap in species composition across sampling sites (Krištín et al 2019) and during our numerous surveys, we recorded 3 times more morphospecies of Ensifera than the total amount of species considered occurring in the island, suggesting that most of Madagascar's Orthopteran diversity remains to be described.

In the present article, I record for the first time shield-backed katydids of tribe Arytropteridini Caudell, 1908 from Madagascar. Until now, all Arytropteridini were only known from Southern Africa (Rentz 1988, Naskrecki 1992). We propose the new genus Toliaridectes $n$. gen. to 
include Toliaridectes meridionalis n. gen. n. sp., Toliaridectes wendenbaumi n. gen. n. sp. and Toliaridectes antsycurvis n. gen. n. sp..

\section{Material and methods}

The new taxa described in the present paper are based on specimens recently collected in Madagascar by the author and Nicolas Cliquennois (Antsirabe). All samples were collected by sight after dark, using a headlamp. The number following the name of the collector corresponds to field pad number of the specimen, and is printed in the first label pinned on the specimen. Additional specimens were found in non-identified material of MNHN. Measurements. The measurements have been performed on dry specimens following Rentz (1988).

Acoustics. Sounds were acquired with an Audiotechnica AT822 stereo microphone, on a NIKON D5200 camera (sampling rate: $96 \mathrm{kHz}$ ) with a red illumination (to follow the insect behavior). Song analysis has been performed with Clampfit 10.2 software. Song recordings are deposited in both coll. S.H. and MNHN acoustic databases: https://sonotheque.mnhn.fr/. Acoustic terminology is from Stumpner et al. (2013).

Specimen repository. CAS, California Academy of Sciences (CA, USA); MNHN, Muséum national d'Histoire naturelle (France); coll. SH, Collection Sylvain Hugel, Strasbourg, France.

\section{Results}

List of Arytropteridini Caudell, 1908 genera:

Arytropteris Herman, 1874 [Southern-Africa]

Thoracistus Pictet, 1888 [Southern-Africa]

Anarytropteris Uvarov, 1924 [Southern-Africa]

Ceresia Uvarov, 1928 [Southern-Africa]

Alfredectes Rentz, 1988 [Southern-Africa]

Zuludectes Rentz, 1988 [Southern-Africa]

Transkeidectes Naskrecki, 1992 [Southern-Africa]

Toliaridectes n. gen. [Madagascar]

Toliaridectes meridionalis n. gen. n. sp. [Madagascar, Anôsy and Androy regions]

Toliaridectes wendenbaumi n. gen. n. sp. [Madagascar, Atsimo-Andrefana region]

Toliaridectes antsycurvis n. gen. n. sp. [Madagascar, Atsimo-Andrefana region] 


\section{Genus Toliaridectes $\mathbf{n}$. gen.}

Type species. Toliaridectes antsycurvis n. gen., n. sp, here designated.

Distribution. South-Eastern Madagascar.

Diagnosis. Toliaridectes $\mathrm{n}$. gen. is characterized by: Fastigium of vertex narrower than antennal scape (Fig. 1-3; as broad or broader in Zuludectes, Anarytropteris, Namaquadectes, Thoracistus, Alfredectes), no fastigial gap (Fig. 4-6; with a gap in Arytropteris). Pronotum little modified (Fig. 1-6; elongate in males of Thoracistus, Alfredectes, some Arytropteris), not exceeding first abdominal segment. Ventral surface of fore and mid femora armed with minute teeth (Fig. 1; unarmed in Zuludectes). Fore tibia unarmed dorsally (Fig. 10-15; armed in all other Arytropteridini). Mid tibia armed with 3 dorsal posterior spurs, not armed on dorsal anterior surface (Fig. 16-21; armed in all other Arytropteridini). Male forewings with fewer than 45 teeth (Fig. 27, 30, 33; when known, >49 in all Arytropteridini except Zuludectes).

Description. Body size average for the tribe, form robust.

Color. General coloration brown with dark and light patterns (Fig. 68-71). Face with sagittal black pattern from antennal sockets to labrum tip. Black retro-ocular patterns often edged with dorsal light pattern. Scapus and pedicel with black patterns. Pronotum folds (see Rentz 1988) with black pattern in line with retroocular black lines, often edged dorsally with light stripes; ventral and posterior rims of lateral lobes black. Abdomen with black patterns laterally, often edged dorsally with light stripes. Hind femur outer field with a dark or black longitudinal pattern.

Head. Head in frontal view 1.4-1.8 times higher than wide, narrower than pronotum in dorsal view (Fig. 1-3). Fastigium verticis narrower than scapus (Fig. 1-3), triangular in frontal view (Fig. 7-9), no fastigial gap between fastigium verticis and fastigium frontis, fastigium frontis contacting the fastigium verticis in a narrow ridge (Fig. 4-9). Median ocellus very distinct, in line with ventral part of antennal scrobus (Fig. 7-9). Genae with no carinae. Scapus unarmed. Thorax. Pronotum little modified, slightly different in males and females, in both cases not exceeding first abdominal segment, not producing posteriorly, without median carina, without lateral carinae, rims of lateral lobe and disk not enlarged; disk flat in side view, arched in cross section; anterior margin inconspicuously concave; posterior margin broadly rounded; surface of disk smooth, faintly shining; disk prozona traversed by a transverse sulcus shaped 
as a curly bracket (Fig. 1-3). Prosternum armed with a pair of broadly spaced blunt erected spines; meso and metasternum with a pair of more robust processes.

Wings. Forewings present in males, absent in females.

Legs. Leg surface covered with numerous minute imprints, often pigmented and bearing a small seta. Fore coxa with one median antero lateral spine, relatively flattened (Fig. 1-3). Fore femora with 1-4 minute spinules in anterior and posterior ventral margins (rarely none on posterior margin of $T$. antsycurvis n. gen. n. sp.); fore femora genicular lobes with 2 very small spinules on both sides. Fore tibia (Fig. 10-15): with 6 ventral inner spurs (including apical spur); with 6 ventral outer spurs (including apical spur); without dorsal apical and subapical spurs. Auditory foramen narrow, slit shaped, visible in side view (Fig. 10-15). Mid coxa with a short ventral blunt process. Mid femora with 2-5 minute spinules in anterior and posterior ventral margins (rarely absent on posterior margin of $T$. antsycurvis n. gen. n. sp.); mid femora genicular lobes with 2 very small spinules on both sides. Mid tibia (Fig. 16-21): with 3 dorsal posterior subapical spurs; without dorsal apical spurs; with 6 ventral inner spurs (including apical spur); with 6 ventral outer spurs (including apical spur). Hind coxa with a short ventral blunt process. Hind femora with 6-10 spines on ventral inner and ventral outer carinae (Fig. 22-24); hind femora genicular lobes with a minute spine on each side.

Abdomen. Tergites with inconspicuous longitudinal carina (Fig. 1-3).

Male. Pronotum (Fig. 1-6) reaching the middle of the first abdominal segment; disk more arched in cross section than in females, leaving room for the wings. Forewings (Fig. 1-3, 2533) slightly exceeding hind margin of pronotum, reaching the distal margin of the first abdominal segment; visible part of the forewing white or light green; file with 38-42 teeth, largest on the middle. $X^{\text {th }}$ abdominal tergite posterior end with a median quadrangular notch of variable width separating two pointing lobes (Fig. 36, 43, 50). Paraprocts very small, with a ventral-median projection variable in size (Fig. 35, 42, 49). Subgenital plate (Fig. 34, 41, 48): broadly triangular in ventral view, with a shallow median notch between styli; with distinct styli. Cercus (Fig. 37-40, 44-47, 51-54) elongate, proximal half broad, distal half narrow, with two projections on the middle: one dorsal lobe pointing toward midline, one median projection pointing toward midline. Titillators well sclerotized, external (distal) part pointing (Fig. 55, 56) or enlarged (Fig. 57) distally in dorsal view, with minute denticles; internal (proximal) part with two branches forming an inverted $Y$ or T (Fig. 55-57). 
Female. Pronotum hardly reaching metathoracic posterior margin, disk more flattened posteriorly than in males. Wings absent. Suranal plate small, triangular or rounded, with or without a longitudinal sulcus. Subgenital plate (Fig. 58,60,62) of variable shape, posterior end with a median emargination of variable width and depth separating two pointing lobes. Ovipositor (Fig. 59, 61, 63) flattened proximally, upcurved distally; the flattened part of variable length.

Derivation of name: Named after the Malagasy province "Toliara" where all known species of Toliaradectes n. gen. occur (Fig. 72).

\section{Toliaridectes meridionalis n. gen. n. sp.}

Fig. 1, 4, 7, 10, 13, 16, 19, 22, 25-27, 34-40, 55, 58-59, 72, Tab. 1.

Toliaridectes meridionalis n. gen. n. sp., here described.

Holotype male. Madagascar, province Toliara, région Anôsy, Réserve de Berenty; $25.0096^{\circ} \mathrm{S}$, 46.3079²E, 26.iii.2005, N. Cliquennois leg., MNHN (MNHN-EO-ENSIF 10799).

Male paratype. [Madagascar, province Toliara, region Androy, district Beloha], Beloha; iii.56. AR.

Female (not a type). Madagascar, province Toliara, région Anôsy, Réserve de Sainte-Luce; $24.8028^{\circ} \mathrm{S}, 47.1636^{\circ} \mathrm{E}, 15$. iii.2005, N. Cliquennois leg., coll. SH.

Remark: since the female has been collected in a relatively distinct area (ca. $90 \mathrm{~km}$ apart), in a more humid and coastal environment, I prefer to exclude it from the type series since further specimens may prove it to belong to another species.

Other females possibly belonging to that species but from more northern localities: [Madagascar, province Toliara, region Atsimo-Andrefana,] Sakaraha, Lambomakandro, III-56 A.R., MNHN; Lohela, Mahala, 11.VI.1964; Madagascar Sud, D. Wintrebert Rec., MNHN; LoHena, Mahala, 11.VI.1964 Madagascar Sud, D. Wintrebert Rec., MNHN.

Diagnosis. Color: hind femur with distinct shiny black longitudinal pattern on external (outer) field (Fig. 22, similar pattern in T. wendenbaumi n. gen. n. sp., pattern weaker in T. antsycurvis n. gen. n. sp.). Male. $X^{\text {th }}$ abdominal tergite emargination as deep as wide (Fig. 36; similar in $T$. wendenbaumi n. gen. n. sp., wider in T. antsycurvis n. gen. n. sp.); paraprocts with a long digitiform projection (Fig. 35; wide and short projection in T. wendenbaumi n. gen. n. sp., shorter digitiform projection in T. antsycurvis n. gen. n. sp.). Cercus median projection long (Fig. 37; as long as in T. antsycurvis n. gen. n. sp., shorter in T. wendenbaumi n. gen. n. sp.). 
Subgenital plate wider than long (Fig. 34; similar in T. antsycurvis n. gen. n. sp., longer than wide in T. wendenbaumi n. gen. n. sp.). Titillators distal end pointing (Fig. 55; similar in $T$. wendenbaumi n. gen. n. sp., enlarged distally in T. antsycurvis n. gen. n. sp.). Female. Subgenital plate wider than long, with $U$ shaped emargination (Fig. 58; wider than long in $T$. antsycurvis n. gen. n. sp., about as long as wide in T. wendenbaumi n. gen. n. sp.). Ovipositor very long for the genus (Fig. 59, Table 1).

Description. Size average for the genus (Table 1). Color (male holotype and females only; the male paratype is discolored): head genae without distinct black pattern; hind femur with distinct shiny black longitudinal pattern on external (outer) field (Fig. 22). Male. $X^{\text {th }}$ abdominal tergite emargination as deep as wide (Fig. 36); paraprocts with a long digitiform projection (Fig. 35). Cercus dorsal lobe with angulose tip; median projection long, bilobate (Fig. 37-40). Subgenital plate wider than long; with shallow but distinct emargination; styli separated by less than styli length (Fig. 34). Titillators distal end pointing; internal part shaped as inverted narrow Y (Fig. 55). File with ca. 38 teeth (Fig. 27). Female. Subgenital plate wider than long, with $U$ shaped emargination (Fig. 58). Ovipositor very long for the genus, ventral margin with a long strait area (Fig. 59, Table 1).

Deriviatio nominis. After the distribution of the species, in the South of Madagascar.

\section{Toliaridectes wendenbaumi n. gen. $\mathrm{n} . \mathrm{sp}$.}

Fig. 2, 5, 8, 11, 14, 17, 20, 23, 28-30, 41-47, 56, 60-61, 68-69, 72, Tab. 2.

Toliaridectes wendenbaumi n. gen. n. sp., here described.

Holotype male. Madagascar, province Toliara, région Atsimo-Andrefana, Ambalamanga, confluence Ankolisky/Mangoky, Expédition Makay 2011 - camp 3, 21.675 ${ }^{\circ} \mathrm{S}, 44.9933^{\circ} \mathrm{E}, 19$ 22.i.2011, S. Hugel leg. (2011MADASH 429), MNHN (MNHN-EO-ENSIF10800).

Paratypes. Same as holotype (2011MADASH 373, $\&$ Allotype), MNHN (MNHN-EOENSIF10801). Same as holotype (2011MADASH428 on, $430 \uparrow, 431 \%)$, coll. SH. Same as holotype (2011MADASH371 \%), CAS (CASENT0872622). Madagascar, province Toliara, région AtsimoAndrefana, Antsoa, rivière Androsi, Expédition Makay 2011 - camp 1, 21.596 $\mathrm{S}, 45.1131^{\circ} \mathrm{E}, 19$ 22.i.2011, S. Hugel leg. (2011MADASH 190 \%). [Madagascar, province Toliara, region Mandabe,] Besely (Mandabe), 11.v.1964, Madagascar Sud, D. Wintrebert Rec., ox, MNHN. [Madagascar, province Toliara, region Atsimo-Andrefana,] Tulear, Manombo, 10-v-56, \&, 
MNHN. [Madagascar, province Toliara, region Atsimo-Andrefana,] Sakaraha, Lambomakandro, III-56 A.R., \&, MNHN.

Diagnosis. Color: hind femur with distinct shiny black longitudinal pattern on external (outer) field (Fig. 23, similar pattern in T. meridionalis n. gen. n. sp., pattern weaker in T. antsycurvis n. gen. n. sp.). Male. $X^{\text {th }}$ abdominal tergite emargination as deep as wide (Fig. 43; similar in $T$. meridionalis n. gen. n. sp., wider in T. antsycurvis n. gen. n. sp.); paraprocts with a short wide projection (Fig. 42; long digitiform projection in T. meridionalis n. gen. n. sp., shorter digitiform projection in T. antsycurvis n. gen. n. sp.). Cercus median projection relatively short (Fig. 44; longer in T. antsycurvis n. gen. n. sp. and T. meridionalis n. gen. n. sp.). Subgenital plate longer than wide (Fig. 41; wider than long in T. meridionalis n. gen. n. sp. and T. antsycurvis n. gen. n. sp.). Titillators distal end pointing (Fig. 56; similar in T. meridionalis n. gen. n. sp., enlarged distally in T. antsycurvis n. gen. n. sp.). Female. Subgenital plate about as wide as long, with Vshaped emargination (Fig. 60; wider than long in T. meridionalis n. gen. n. sp. and T. antsycurvis n. gen. n. sp.). Ovipositor average for the genus (Fig. 61, Table 2).

Description. Size average for the genus (Table 2). Color: head with genae without distinct black pattern; pronotum folds with usually a light band edging the black band; hind femur with distinct shiny black longitudinal pattern on external (outer) field (Fig. 23). Male. $X^{\text {th }}$ abdominal tergite emargination as deep as wide (Fig. 43); paraprocts with a shirt wide projection (Fig. 42). Cercus dorsal lobe broadly rounded; median projection relatively short, bilobate (Fig. 4447). Subgenital plate longer than wide; with indistinct emargination; styli separated by about styli length (Fig. 41). Titillators distal end pointing; internal part shaped as inverted wide Y (Fig. 56). File with ca. 42 teeth (Fig. 30). Female. Subgenital plate longer than wide, with $V$ shaped emargination (Fig. 60). Ovipositor average for the genus, ventral margin with a relatively long strait area (Fig. 61, Table 2).

Derivation of name. Named after Evrard Wendenbaum, founder of Naturevolution NGO who organized multiple field surveys in Makay.

\section{Toliaridectes antsycurvis $\mathbf{n}$. gen. $\mathbf{n}$. sp.}

Fig. 3, 6, 9, 12, 15, 18, 21, 24, 31-33, 48-54, 57, 62-67, 70-72, Tab. 3.

Toliaridectes antsycurvis n. gen. n. sp., here described. 
Holotype male. Madagascar, province Toliara, région Atsimo-Andrefana, Tulear II, ManomboSud, Andrevo-Bas, $23.1524^{\circ} \mathrm{S}, 43.6270^{\circ} \mathrm{E}, 15-16 . i i .2019$, S. Hugel leg. (2019MADASH 043), MNHN (MNHN-EO-ENSIF10802).

Paratypes. Madagascar, province Toliara, région Atsimo-Andrefana, Tulear II, Manombo-Sud, Ranobe, $23.0033^{\circ} \mathrm{S}, 43.6233^{\circ} \mathrm{E}, 21$. ii.2019, S. Hugel leg. (2019MADASH 186, o Allotype), MNHN (MNHN-EO-ENSIF10803). same as holotype, (2019MADASH 011, 042 o'), coll. SH. same as allotype, (2019MADASH 187 9), CAS (CASENT0872623). Madagascar, province Toliara, région Atsimo-Andrefana, Tulear II, Belalanda, Ifaty, $23.1413^{\circ} \mathrm{S}, 43.6152^{\circ} \mathrm{E}, 18 . \mathrm{ii} .2019$, S. Hugel leg. (2019MADASH 068 on, 069 \$), coll. SH. Madagascar, province Toliara, région AtsimoAndrefana, Tulear II, Belalanda, Tsivonoe, $23.1502^{\circ} \mathrm{S}, 43.6268^{\circ} \mathrm{E}, 18 . i \mathrm{i} .2019$, S. Hugel leg. (2019MADASH 145 \%), coll. SH.

Diagnosis. Color: hind femur with weak dark longitudinal pattern on external (outer) field (Fig. 24, shiny black pattern in T. meridionalis n. gen. n. sp. and T. wendenbaumi n. gen. n. sp.). Male. $X^{\text {th }}$ abdominal tergite emargination wider than deep (Fig. 50; narrower in $T$. wendenbaumi n. gen. n. sp. and T. meridionalis n. gen. n. sp.); paraprocts with a short narrow projection (Fig. 49; long digitiform projection in T. meridionalis n. gen. n. sp., short and wide in T. wendenbaumi n. gen. n. sp.). Cercus median projection long (Fig. 51; shorter in $T$. wendenbaumi n. gen. n. sp.). Subgenital plate wider than long (Fig. 48; wider than long in $T$. meridionalis n. gen. n. sp., longer than wide in T. wendenbaumi n. gen. n. sp.). Titillators enlarged distally (Fig. 57; pointing in T. meridionalis n. gen. n. sp. and T. wendenbaumi n. gen. n. sp.). Female. Subgenital plate wider than long, with shallow rounded emargination (Fig. 62; longer than wide in T. wendenbaumi n. gen. n. sp.). Ovipositor short for the genus (Fig. 63, Table 3).

Description. Size rather small for the genus (Table 3). Color: head genae with distinct black pattern and dots; pronotum folds with usually without a light band edging the black band; hind femur with weak dark longitudinal pattern on external (outer) field (Fig. 24). Male. $X^{\text {th }}$ abdominal tergite emargination wider than deep (Fig. 50); paraprocts with a short narrow projection (Fig. 49). Cercus dorsal lobe angulose; median projection long, bilobate (Fig. 51-54). Subgenital plate wider than long; with distinct emargination; styli separated by more than styli length (Fig. 48). Titillators enlarged distally; internal part shaped as inverted wide T (Fig. 57). File with ca. 39 teeth (Fig. 33). Female. Subgenital plate with a shallow rounded emargination 
(Fig. 62). Ovipositor short for the genus, straight area of ventral margin short (Fig. 63, Table 3).

Acoustic behavior (Figures 64-67, 70). Males of Toliaridectes antsycurvis n. gen. n. sp. sing at night; we have not recorded calls by day hours. Males adopt a peculiar position while singing, the abdomen bent downwards allowing to release the forewings from the pronotum (Fig. 70). I recorded one male by night at 0 h30 a.m. and $30^{\circ} \mathrm{C}$. This call was mostly in the ultrasound range (peaking above $20 \mathrm{kHz}$ ). It was made of very long repetitions (minutes) of short phonatomes repeated every $46.5 \pm 0.3 \mathrm{~ms}$ (corresponding to $21.7 \mathrm{~Hz}$ ). Phonatomes were made of 5-7 pulses of increasing amplitude (Fig. 67; small pulses may have been missed in the noise). Phonatome duration is $29.0 \pm 0.4 \mathrm{~ms}$.

Derivation of name. Antsy (Malagasy): knife; curvis (latin): curved. After the shape of ovipositor.

\section{Discussion}

Distribution and Endemism. Although endemism in Madagascar is very high, this island harbors many cosmotropical ensifera species such as Natula longipennis (Serville, 1838), Gryllodes sigillatus (Walker; 1869), and many others. The endemic/non endemic status of the new species described in the present article may therefore be questioned, particularly for $T$. antsycurvis n. gen. $\mathrm{n}$. sp. and T. meridionalis $\mathrm{n}$. gen. $\mathrm{n}$. sp. living near the coast and near villages. Nevertheless, all three species are close from each other and distinct enough from all other Arytropteridini to group them in a distinct new genus. This strongly suggests that this genus as well as the three species included are endemic to Madagascar.

Interestingly, other groups of Orthoptera originally described as having a localized distribution in Southern Africa have been later recorded in South Western Indian Ocean islands, such as the genus Taciturna Otte, 1987 (Hugel 2014).

Biology. As the vast majority of Malagasy endemic Ensifera, Toliaridectes n. gen. is mostly nocturnal and virtually impossible to observe by day hours. All three species occur in sandy areas harboring spiny thickets. Some specimens were observed eating other insects such as crickets or caterpillars (Fig. 69). One female of T. antsycurvis n. gen. n. sp. was observed while ovipositing in sand (Fig. 71). All specimens were close to the ground (less than $50 \mathrm{~cm}$ ), usually at the heart of dense bushes (Fig. 70), making them difficult to catch. All specimens were present in relatively well preserved spots; none was observed within cultures. 
Taxonomic position of Toliaridectes $\mathbf{n}$. gen. In this new genus, fore tibia are dorsally nonarmed whereas fore tibia of all previously described Arytropteridini display 2 (rarely 1 ) dorsal outer subapical spurs. All other characters of this new genus correspond to those of Arytropteridini listed by Storozhenko (1994). I therefore propose to place Toliaridectes n. gen. within Arytropteridini.

Taxonomic position of Arytropteridini. Taxonomic history of shield-backed katydids has been detailed by Rentz (1988) even before Storozhenko (1994) formally exhumed Arytropteridini from Caudell's "Arytropterees" (1908). Arytropteridini are currently under Tettigoniinae (Cigliano et al 2019). Interestingly, following Beier's key (1962), in Tettigoniinae as well as in Mecopodinae and Phyllophorinae fore tibia are dorsally armed with at least one dorsal outer spur. Arytropteridini are devoid of dorsal apical spurs on fore tibia and, therefore, do not comply with Beier's definition of Tettigoniinae. The opinion that Arytropteridini do not belong to Tettigoniinae is further reinforced by molecular data suggesting that Arytropteridini reveal the Tettigoniinae paraphyletic (Mugleston et al 2013). Following strictly Beier's key would place Arytropteridini in Listroscelidinae, but this subfamily is most likely paraphyletic in its current definition (Mugleston et al 2013). Should data from Mugleston et al (2013) be confirmed, a taxon including Rentz's (2001) Listroscelidinae Redtenbacher, 1891 (i.e. Terpandrini Gorochov, 1990; Hexacentrini Karny, 1925; Requenini Rentz, 2001; Conocephalomimini Rentz, 2001; Phisidini Jin, 1987) together with Meconematini Burmeister, 1838, Arytropteridini Caudell, 1908 and -more surprisingly- Hetrodinae Brunner von Wattenwyl, 1878 would probably have to be defined.

Acknowledgments. The fieldwork on which this study is based could not have been completed without the gracious support of the Malagasy people, Brian Fisher (California Academy of Science) and all the arthropod team of the Madagascar Biodiversity Center for their help and advices, particularly Balsama Rajemison, Jean-Claude Rakotonirina, Jean-Jacques Rafanomezantsoa, Chrislain Ranaivo, Hanitriniana Rasoazanamavo, Nicole Rasoamanana, Clavier Randrianandrasana, Dimby Raharinjanahary, Njaka Ravelomanana, Manoa Ramamonjisoa. I thank Naturevolution team (https://www.naturevolution.org/) and particularly Evrard Wendenbaum for having organized multiple surveys in Makay region. I thank Nicolas Cliquennois for his continuous and fruitful efforts to collect Orthoptera in South Western Indian Ocean islands. Thanks to Darren Goldin and Aran Hinton for their help in the 
field in Tulear. I thank Steve Goodman for his precious advices. This work was conducted with support from Insects and People of the Southwest Indian Ocean (IPSIO, https://www.ipsio.org), a network funded by the Critical Ecosystem Partnership Fund (CEPF). Permits to research, collect and export arthropods were obtained from the Ministry of Environment and Forest as part of an ongoing collaboration between the Madagascar Biodiversity Center, and the Ministry of Environment and Forest, Madagascar National Parks and Parc Botanique et Zoologique de Tsimbazaza.

\section{References}

Beier, M. (1962) Orthoptera Tettigoniidae (Pseudophyllinae I). In: Mertens, R., Hennig, W. \& Wermuth, H. Das Tierreich 73. Walter de Gruyter \& Co., Berlin, pp. 1-468.

Caudell, A.N. (1908) Orthoptera Fam. Locustidae Subfam. Decticinae. In: Wytsman, P., Genera Insectorum 72. V. Verteneuil \& L. Desmet, Bruxelles, pp. 1-42.

Cigliano, M.M., H. Braun, D.C. Eades \& D. Otte. Orthoptera Species File. Version 5.0/5.0. 02.x.2019. http://Orthoptera.SpeciesFile.org

Gorochov, A.V. (2017) New taxa of the subfamily meconematinae (Orthoptera: Tettigoniidae) from Africa and adjacent islands. Proceedings of the Zoological Institute RAS, 321(1), 3264. http://www.zin.ru/journals/trudyzin/doc/vol 321 1/TZ 3211 Gorochov.pdf

Heller, K.G., Hemp, C., Massa, B., Kociński, M., Warchałowska-Śliwa, E. (2018) Paraplangia sinespeculo, a new genus and species of bush-cricket, with notes on its biology and a key to the genera of Phaneropterinae (Orthoptera: Tettigonioidea) from Madagascar. Journal of Orthoptera Research, 27, 143-153. https://doi.org/10.3897/jor.27.24243

Heller, K.G., Hemp, C., Massa, B., Rakotondranary, J., Krištín, A. (2019) Notes on a small collection of phaneropterine bush-crickets (Insecta: Orthoptera: Tettigonioidea) from central and southern Madagascar with the description of two new species. Zootaxa, 4563, 297-310. http://dx.doi.org/10.11646/zootaxa.4563.2.4

Hugel, S. (2012) New and little known Phisidini from Madagascar, Comoro and Seychelles (Ensifera: Meconematinae). Zoosystema, 34(3), 525552. https://doi.org/10.5252/22012n3a3

Hugel, S. (2014) Burrowing crickets endemic to summits in Mauritius (Orthoptera, Gryllidae): occupation of similar niches by species possibly derived from Australasian and African colonists. Zootaxa, 3852(3), 382-390. http://dx.doi.org/10.11646/zootaxa.3852.3.7 
Krištín, A., Heller, K.G., Zemko M., Rakotondranary, J., Jarčuška, B. (2019) Assemblages of orthopteroid insects along environmental gradients in central and southern Madagascar. Journal of Orthoptera Research, 28(2), 165-166. https://doi.org/10.3897/jor.28.34055

Mugleston, J.D., Song, H., Whiting, M.F. (2013) A century of paraphyly: a molecular phylogeny of katydids (Orthoptera: Tettigoniidae) supports multiple origins of leaf-like wings. Molecular Phylogenetics and Evolution, 69(3), 1120-1134. https://doi.org/10.1016/i.ympev.2013.07.014

Naskrecki, P. (1992) A new genus and species of South African Tettigoniinae (Orthoptera: Tettigoniidae). Journal of Orthoptera Research, 1, 73-74.

Rentz, D. C. F. (1988) The shield-backed katylids of Southern Africa: their taxonomy, ecology and relationships to the faunas of Australia and South America (Orthoptera: Tettigoniidae: Tettigoniinae). Invertebrate Systematics, 2 (2), 223335. https://doi.org/10.1071/IT9880223

Rentz, D.C.F. (2001) Tettigoniidae of Australia. Volume 3. The Listroscelidinae, Tympanophorinae, Meconematinae and Microtettigoniinae. CSIRO Publishing, Collingwood, pp. 1-524.

Storozhenko, S.Y. (1994) Revision of the Tribe Onconotini with a Description of a New Tribe (Orthoptera, Tettigoniidae, Tettigoniinae). Journal of Orthoptera Research, 2, 6568. https://www.jstor.org/stable/3503612

Stumpner, A., Dann, A., Schink, M., Gubert, S. \& Hugel, S. (2013) True katydids (Pseudophyllinae) from Guadeloupe: Acoustic signals and functional considerations of song production. Journal of Insect Science, 13 (157), 116. https://doi.org/10.1673/031.013.15701

Ünal, M., Beccaloni, G.W. (2017) Revision of the Madagascan genera Oncodopus Brongniart and Colossopus Saussure (Orthoptera: Tettigoniidae: Conocephalinae; Euconchophorini), with description of Malagasopus gen. nov. Zootaxa, 4341, 193228. https://doi.org/10.11646/zootaxa.4341.2.2 
FIGURES 1-9. Toliaridectes $\mathbf{n}$. gen. male head and pronotum. 1-3: head and pronotum in dorsal view, before removing the forewings for examination. 4-6: head and pronotum in left side view. 7-9: face in frontal view. 1, 4, 7: Toliaridectes meridionalis n. gen. n. sp. 2, 5, 8: Toliaridectes wendenbaumi n. gen. n. sp. 3, 6, 9: Toliaridectes antsycurvis n. gen. n. sp. All pictured specimens are holotypes.

FIGURES 10-24. Toliaridectes n. gen. legs. 10-12: left fore tibia inner view. 13-15: left fore tibia outer view. 16-18: left mid tibia anterior view. 19-21: left mid tibia posterior view. 2224: left hind femur outer view. 10,13, 16, 19, 22: Toliaridectes meridionalis n. gen. n. sp. 11, 14, 17, 20, 23: Toliaridectes wendenbaumi n. gen. n. sp. 12, 15, 18, 21, 24: Toliaridectes antsycurvis n. gen. n. sp. All pictured specimens are holotypes.

FIGURES 25-33. Toliaridectes $n$. gen. male forewings. 25, 28, 31: left forewing in dorsal view (removed from specimen). 26, 29, 32: right forewing in dorsal view (removed from specimen). 27, 30, 33: file in ventral view. 25-27: Toliaridectes meridionalis n. gen. n. sp. 28-30: Toliaridectes wendenbaumi n. gen. n. sp. 31-33: Toliaridectes antsycurvis n. gen. n. sp. All pictured specimens are holotypes.

FIGURES 34-54. Toliaridectes $\mathbf{n}$. gen. male terminalia. 34, 41, 48: subgenital plate (ventral view). 35, 42, 49: left paraproct (removed from specimen). 36, 43, 50: male suranal plate (dorsal view, the subgenital plate is lightened for better visualization). 37, 44, 51: left cercus (dorsal view). 38, 45, 52: left cercus (inner view). 39, 46, 53: left cercus (ventral view). 40, 47, 54: left cercus (outer view). 34-40: Toliaridectes meridionalis n. gen. n. sp. 41-47: Toliaridectes wendenbaumi n. gen. n. sp. 48-54: Toliaridectes antsycurvis n. gen. n. sp. All pictured specimens are holotypes.

FIGURES 55-57. Toliaridectes $\mathbf{n}$. gen. male genitalia (dorsal view, posterior side on top). 55: Toliaridectes meridionalis n. gen. n. sp. 56: Toliaridectes wendenbaumi n. gen. n. sp. 57: Toliaridectes antsycurvis n. gen. n. sp. All pictured specimens are holotypes.

FIGURES 58-63. Toliaridectes $\mathbf{n}$. gen. female terminalia. 58, 60, 62: subgenital plate (ventral view, posterior side on top). 59, 61, 63: ovipositor (left side view). 58-59: Toliaridectes 
meridionalis n. gen. n. sp. 60-61: Toliaridectes wendenbaumi n. gen. n. sp. 6263: Toliaridectes antsycurvis n. gen. $\mathbf{n}$. sp.

FIGURES 64-67. Toliaridectes antsycurvis n. gen. $n$. sp. male call. Specimen 2019MADASH042 recorded in natura in Andrevo Bas $30^{\circ} \mathrm{C} 15-16 . i i .2019$ at 0h30, few seconds before taking the picture from figure 70 .

FIGURES 68-71. Toliaridectes n. gen. in natura. 68-69: Toliaridectes wendenbaumi $\mathbf{n}$. gen. $\mathbf{n}$. sp., male in resting position (68); female eating a caterpillar (69). 70-71: Toliaridectes antsycurvis n. gen. n. sp., male calling (70; specimen 2019MADASH042, see figures 64-67); female in oviposition (71).

FIGURE 72. Distribution of Toliaridectes $\mathrm{n}$. gen.

Tables

TABLE 1. Measurements of Toliaridectes meridionalis n. gen. n. sp. (in mm).

\begin{tabular}{|c|c|c|c|c|c|c|c|c|c|}
\hline & & $\begin{array}{l}\text { Body } \\
\text { length }\end{array}$ & $\begin{array}{c}\text { Pronotum } \\
\text { length }\end{array}$ & $\begin{array}{c}\text { Pronotum } \\
\text { width }\end{array}$ & $\begin{array}{l}\text { Fore } \\
\text { femur } \\
\text { length }\end{array}$ & $\begin{array}{l}\text { Mid } \\
\text { femur } \\
\text { length }\end{array}$ & $\begin{array}{l}\text { Hind } \\
\text { femur } \\
\text { length }\end{array}$ & $\begin{array}{l}\text { Hind } \\
\text { femur } \\
\text { width }\end{array}$ & $\begin{array}{c}\text { Ovipositor } \\
\text { length }\end{array}$ \\
\hline$\sigma^{x}$ & Holotype & 17.5 & 6.4 & 4.7 & 5.7 & 5.3 & 16.1 & 3.4 & - \\
\hline 웅 & & 21.4 & 7.1 & 6.8 & 7.0 & 6.2 & 20.4 & 3.8 & 14.5 \\
\hline
\end{tabular}

TABLE 2. Measurements of Toliaridectes wendenbaumi n. gen. n. sp. (in mm).

\begin{tabular}{|c|c|c|c|c|c|c|c|c|c|}
\hline & & $\begin{array}{l}\text { Body } \\
\text { length }\end{array}$ & $\begin{array}{c}\text { Pronotum } \\
\text { length }\end{array}$ & $\begin{array}{c}\text { Pronotum } \\
\text { width } \\
\end{array}$ & $\begin{array}{l}\text { Fore } \\
\text { femur } \\
\text { length }\end{array}$ & $\begin{array}{l}\text { Mid } \\
\text { femur } \\
\text { length }\end{array}$ & $\begin{array}{l}\text { Hind } \\
\text { femur } \\
\text { Length }\end{array}$ & $\begin{array}{l}\text { Hind } \\
\text { femur } \\
\text { width }\end{array}$ & $\begin{array}{c}\text { Ovipositor } \\
\text { length }\end{array}$ \\
\hline \multirow[t]{2}{*}{$0^{x}$} & Holotype & 17.6 & 6.1 & 4.3 & 4.9 & 4.8 & 15.5 & 3.2 & - \\
\hline & $\begin{array}{l}\text { Paratype } \\
428\end{array}$ & 16.0 & 6.1 & 4.8 & 5.5 & 5.5 & 16.3 & 3.1 & - \\
\hline \multirow[t]{3}{*}{ ㅇ } & Allotype & 21.9 & 6.4 & 5.4 & 6.2 & 6.3 & 19.7 & 3.5 & 12.4 \\
\hline & $\min$ & 21.3 & 6.2 & 5.4 & 6.2 & 6.1 & 18.6 & 3.5 & 11.2 \\
\hline & $\max$ & 23.0 & 6.4 & 5.6 & 7.0 & 6.7 & 19.7 & 3.6 & 13.9 \\
\hline
\end{tabular}

TABLE 3. Measurements of Toliaridectes antsycurvis n. gen. $\mathbf{n}$. sp. (in mm). 


\begin{tabular}{|c|c|c|c|c|c|c|c|c|c|}
\hline & & $\begin{array}{l}\text { Body } \\
\text { length }\end{array}$ & $\begin{array}{c}\text { Pronotum } \\
\text { length }\end{array}$ & $\begin{array}{c}\text { Pronotum } \\
\text { width }\end{array}$ & $\begin{array}{c}\text { Fore } \\
\text { femur } \\
\text { length }\end{array}$ & $\begin{array}{l}\text { Mid } \\
\text { femur } \\
\text { length }\end{array}$ & $\begin{array}{l}\text { Hind } \\
\text { femur } \\
\text { Length }\end{array}$ & $\begin{array}{l}\text { Hind } \\
\text { femur } \\
\text { width }\end{array}$ & $\begin{array}{c}\text { Ovipositor } \\
\text { length }\end{array}$ \\
\hline \multirow[t]{3}{*}{$0^{x}$} & Holotype & 16.0 & 6.1 & 5.0 & 5.2 & 5.2 & 15.8 & 3.4 & - \\
\hline & $\min$ & 12.9 & 5.6 & 4.1 & 4.5 & 4.5 & 14.4 & 3.0 & - \\
\hline & $\max$ & 16.0 & 6.1 & 5.0 & 5.2 & 5.2 & 15.8 & 3.4 & - \\
\hline \multirow[t]{3}{*}{ q } & Female & 19.7 & 6.8 & 5.7 & 6.2 & 6.0 & 19.0 & 3.9 & 8.8 \\
\hline & $\min$ & 17.7 & 6.8 & 5.7 & 6.2 & 6.0 & 19.0 & 3.6 & 8.8 \\
\hline & $\max$ & 19.7 & 6.9 & 6.2 & 6.7 & 6.7 & 20.1 & 4.2 & 11.9 \\
\hline
\end{tabular}

